\title{
DIE VERKOOP VAN 'N BESIGHEID AS LOPENDE SAAK: BELASTING EN ARBEIDSREG PROBLEME MET "VOORSIENINGS"
}

\author{
Suzanne Kieviet* \\ University of Stellenbosch, South Africa \\ kieviets@sun.ac.za
}

September 2011

\begin{abstract}
The amounts set aside for the provision for employee-related contingent liabilities, such as the provision for leave pay, are often considerable. According to current Income Tax law, it is highly unlikely that the former employer (seller) will enjoy a tax deduction. Furthermore, it is also unlikely that the prospective employer (buyer) will enjoy a tax deduction. In contrast to this, both the former and prospective employers are held liable according to the Labour Relations Act in cases where a business is sold as a going concern. This article concludes that the Draft Taxation Laws Amendment Bill 2011, as envisioned, finally provides clear tax legislation, but still needs to be aligned with the objectives of the Labour Relations Act. In doing so, contradictory legislation will be avoided, thus facilitating the transfer of businesses and achieving the protection of employees' work security.
\end{abstract}

Keywords

Belastingaftrekbaarheid, onderneming, Inkomstebelastingwet, lopende saak, voorwaardelike aanspreeklikhede, voorsienings, werknemerverwante

* Ms Suzanne Kieviet a lecturer in accountancy in the at the University of Stellenbosch, South Africa. 


\section{INLEIDING}

Die verkoop van besighede is ' $\mathrm{n}$ alledaagse verskynsel in die Suid-Afrikaanse besigheidsfeer. Netso is die voorkoms van 'voorsieningsrekeninge' op besighede se finansiële state. Die probleem met 'voorsienings' ontstaan wanneer ' $n$ belastingpligtige sy besigheid as lopende saak verkoop, alvorens hierdie voorwaardelike aanspreeklikhede gerealiseer het (Ger, 2011). Werknemer-verwante voorwaardelike aanspreeklikhede, soos voorsienings vir verlofgelde en bonus-uitbetalings, beloop dikwels wesenlike bedrae (Ger, 2009). Uit ' $n$ regsoogpunt hou hierdie 'voorsienings' dikwels verband met voorwaardelike aanspreeklikhede, naamlik aanspreeklikhede wat sal ontstaan indien ' $n$ voorwaarde nagekom word. ' $n$ Voorbeeld hiervan is 'n bonusbetaling aan ' $n$ werknemer indien die werknemer op toekomstige datum steeds in diens van die werkgewer is. Uit belastingoogpunt verteenwoordig hierdie 'voorsiening' bedrag wat nog nie werklik aangegaan is nie en daarom nie as ' $n$ aftrekking vir belastingdoeleindes toegelaat sal word nie (Ger, 2009). In die normale loop van sake, word die voorwaarde vervul, die verpligting betaal (of betaalbaar), en die belastingpligtige geregtig op ' $n$ aftrekking (Ger, 2011).

In die saak Ackermans Ltd v CSARS, PEP Store (SA) Ltd v CSARS 2011 (1) SA I (SCA) ('Ackermanssaak') is ' $n$ kleinhandelsaak as lopende saak verkoop, en die prys ontvangbaar deur die verkoper (Ackermans) is verminder met die waarde van sekere van die verkoper se voorwaardelike aanspreeklikhede, wat die koper ooreengestem het om oor te neem. Die belastingpligtige (Ackermans) het aangevoer dat die vermindering van die koopsom ' $n$ verlies van vermoënskade was en effektiewelik 'n 'uitgawe werklik aangegaan' verteenwoordig.

Die Hoogste Hof van Appèl het bevind dat geen 'uitgawe werklik aangegaan' is nie, omrede die verkoper ' $n$ gedeelte van die koopsom prysgegee het, wat andersins gehef sou wees indien die koper nie ooreengestem het om sommige voorwaardelike aanspreeklikhede oor te neem nie. Geen aanspreeklikheid is deur die verkoper teenoor die koper opgeloop nie, en die besigheid is bloot teen die netto bate waarde verkoop. Hierdie transaksie het dus geen 'uitgawe werklik aangegaan' vergestalt nie, met die gevolg dat ' $n$ belastingaftrekking geweier is.

Emslie (2010) is van mening dat die posisie dalk anders sou gewees het indien die verkoopstransaksie op ' $n$ ander wyse gestruktureer is.

Die partye betrokke by die onderhandeling, kan die verkoopstransaksie op die volgende metodes struktureer:

- Die koper kan die aanspreeklikhede oorneem en die koopsom verminder met die waarde van die aanspreeklikhede oorgeneem, of

- Die verkoper hef die volle koopsom, maar behou aanspreeklikheid vir die betaling van alle aanspreeklikhede (Ger, 2011).

Indien die Wet op Arbeidsverhoudinge 66 van 1995 (die Arbeidsverhoudingewet) en die Inkomstebelastingwet, 58 van 1962 (die Inkomstebelastingwet) voorts teenstrydige bepalings bevat, mag dit nadelig vir die werknemers wees, aangesien die belastingpligtige sy besluite baseer op die beste ekonomiese gevolg vir hom as ondernemer. Dus, indien die Arbeidsverhoudingewet ' $n$ verpligting daarstel, en die Inkomstebelastingwet weier om ' $n$ aftrekking te bied vir die belastingpligtige, sal die belastingpligtige bes moontlik kies om nie die verpligting op te neem nie. In so ' $n$ geval sal die belastingpligtige moontlik kies om eerder alle werknemers af te dank alvorens hy sy besigheid van die hand sit. ' $n$ Positiewe omgewing daarenteen, waar die Inkomstebelastingwet die oogmerke van die Arbeidsverhoudingewet 
ondersteun, sal egter tot gevolg hê dat die belastingpligtige tot die behoud van werksekuriteit en die skep van werksgeleenthede sal bydra.

\section{DOELWIT EN METODOLOGIE VAN DIE STUDIE}

In hierdie artikel word daar ondersoek ingestel na die Arbeidsverhoudingewet om te bepaal in watter omstandighede die voormalige of voornemende werkgewer verplig word om werknemerverwante betalings te maak nadat besigheid as lopende saak verkoop is. Dit word voorafgegaan deur ondersoek na die Inkomstebelastingwet en die vereistes waaraan werknemerverwante betalings moet voldoen om as aftrekkings toegestaan te word.

Die Konsepwetgewing, wat blyk die probleem gedeeltelik op te los, word kortliks bespreek.

Die struktuur van die artikel is soos volg:

- Omskrywings word verskaf van sekere relevante terme;

- Die toepaslike bepalings van die Inkomstebelastingwet word ondersoek ten einde die belastingaftrekbaarheid vir die voormalige- sowel as voornemende werkgewer te bepaal;

- Die toepaslike bepalings van die Arbeidsverhoudingewet word ondersoek ten einde vas te stel watter verpligtinge op die voormalige en voornemende werkgewer rus by die verkoop van 'n besigheid as lopende saak;

- Konsepwetgewing word kortliks bespreek;

- Sekere gevolgtrekkings en aanbevelings word gemaak.

\section{OMSKRYWINGS}

\subsection{Lopende saak}

Die grondrede vir die inwerkingstelling van Artikel 197 van die Arbeidsverhoudingewet is om werksekuriteit te beskerm in geval van die oordrag van ' $n$ besigheid as lopende saak (Abader, 2003:5). Die oordrag van die hele of slegs gedeelte van ' $n$ besigheid, handelsonderneming, onderneming of diens, as lopende saak is hier ter sprake. Die Arbeidsverhoudingewet bied egter geen omskrywing vir hierdie begrippe nie (Smit, 1997:552).

Volgens The 0xford English Dictionary (online), beteken 'transfer' (oordrag) 'to convey or take from one place, person etc. to another; to transmit, transport; to give or hand over from one to another'.

Indien hierdie definisie aanvaar word vir doeleindes van artikel 197 van die Arbeidsverhoudingewet, blyk dit dat daar geen rede bestaan om die tipe oordragtransaksie wat moontlik mag bestaan, te beperk nie. Al wat benodig word, is ' $n$ transaksie met die effek dat ' $n$ besigheid van een werkgewer na ' $n$ ander verskuif word. Die Arbeidshof meld in Schutte \& Others $v$ Powerplus Performance (Pty) and Another 19992 BLLR 169 (LC) (op bladsy 180), dat ' $n$ wye reeks transaksies bestaan ingevolge waarvan ' $n$ besigheid oorgedra kan word, naamlik: ' $n$ verkoopstransaksie, oordrag, samesmelting, oorname, donasie of die uitruiling van bates. 


\subsection{Voorwaardelike aanspreeklikheid}

'n Voorwaardelike aanspreeklikheid word gedefinieer as:

- ' $n$ moontlike verpligting wat uit vorige gebeure spruit en waarvan die bestaan slegs bevestig sal word deur die plaasvind, of nie, van een of meer onsekere toekomstige gebeure wat nie ten volle binne die beheer van die entiteit is nie, of

- ' $n$ huidige verpligting wat uit vorige gebeure spruit, maar nie erken word nie:

- omdat dit onwaarskynlik is dat ' $n$ uitvloei van hulpbronne vereis sal word, of

- omdat die bedrag van die verpligting nie met genoegsame betroubaarheid gemeet kan word nie (Vorster, Koornhof, Oberholster, Koppeschaar, Coetzee, Janse van Rensburg, Binnekade, Hattingh \& Leith, 2009:843).

\section{BELASTINGAFTREKBAARHEID VIR DIE VOORMALIGE WERKGEWER (VERKOPER)}

Vir enige bedrag om as aftrekking vir inkomstebelastingdoeleindes te kwalifiseer, moet so ' bedrag voldoen aan artikel 11 (a) van die Inkomstebelastingwet, en voorts nie verbied word deur enige van die klousules te vinde in artikel 23 van die Inkomstebelastingwet nie.

Ingevolge artikel 11 (a) van die Inkomstebelastingwet, moet die bedrag

- 'n onkoste of verlies wees wat werklik aangegaan of gely is

- by die voortbrenging van inkomste

- vir bedryfsdoeleindes,

- $\quad$ uitgesluit onkoste en verliese van 'n kapitale aard.

Voorts is die bepalings van artikel $11(a)$ ondergeskik aan die van artikel 23, met spesifieke verwysing na artikel 23(e), waarvolgens:

- Inkomste wat na 'n reserwefonds oorgedra of

- op een of ander wyse gekapitaliseer word,

sal nie as aftrekking by die vasstelling van belasbare inkomste toegestaan word nie. Ingevolge artikel 23(g) moet die bedrag voorts aangegaan wees vir bedryfsdoeleindes.

Die voormalige werkgewer bly ingevolge die Arbeidsverhoudingewet (artikel 197(2)(b)-(d)) aanspreeklik vir die betaling van bedrae, soos en wanneer dit onvoorwaardelik word. Die voormalige werkgewer kan dus (a) ' $n$ bedrag betaal aan die voornemende werkgewer om die verpligtinge mee te vereffen, of (b) ' $n$ bedrag betaal aan die voormalige werknemer soos en wanneer dit betaalbaar word, of (c) gelde oordra na ' $n$ fonds om voorsiening te maak vir die betaling van die verpligtinge.

\subsection{Betaal bedrag aan voornemende werkgewer (koper)}

De Bruin (2000) doen aan die hand dat daar twee maniere is waarvolgens die voornemende werkgewer 'vergoed' kan word vir die oorname van sodanige verpligting. Die voormalige 
werkgewer kan ' $n$ bedrag (waarskynlik gelykstaande aan die uitstaande, of beraamde uitstaande, verpligtinge op datum van oorname) aan die voornemende werkgewer betaal, of die voormalige werkgewer kan die koopprys betaalbaar met ' $n$ ooreenstemmende bedrag verminder, soos die geval in die Ackermans-saak.

\subsubsection{Betaal bedrag aan voornemende werkgewer op datum van oordrag}

Ingevolge artikel 11 (a) van die Inkomstebelastingwet, kan onkoste of verliese werklik aangegaan of gely by die voortbrenging van die inkomste, (mits sodanige onkoste en verliese nie van ' $n$ kapitale aard is nie), as aftrekking vir belastingdoeleindes toegelaat word.

\subsubsection{Onkoste of verlies werklik aangegaan of gely}

In die saak Joffe \& Co (Pty) Ltd v CIR, 13 SATC 354 het die regter (op bladsy 360), met verwysing na handelsbedrywighede, ' $n$ verlies illustreer as die (meesal onwillekeurige) ontneming gely deur 'n party. Daarteenoor dui 'onkoste' op die willekeurige betaling van geld.

Gegewe die algemene aftrekkingsformule, sluit die term: 'onkoste' ook 'verliese gely' in. Ger en Choong (2011) is van mening dat 'onkoste' sy oorsprong in ' $n$ regsverpligting het, terwyl ' $n$ 'verlies' nie so beperkend is nie. ' $n$ Verlies kan vir belastingdoeleindes bestaan waar die belastingpligtige vermoënskade gely het, wat nie noodwendig voorafgegaan is deur ' $n$ regsverpligting nie. (' $n$ Voorbeeld hiervan is handelsvoorraad wat verwoes is in ' $n$ brand.)

In die saak Edgars Stores Ltd v CIR, 1988 (3) SA 764 (A), 50 SATC 81 ('Edgars Stores-saak') is die woorde 'werklik aangegaan' gedefinieer as onkoste waarvoor 'n onvoorwaardelike regsaanspreeklikheid aangegaan is. Steenkamp (1993:8) meld dat die fisiese betaling van ' $n$ uitgawe nie die oorwegende faktor is by die bepaling wanneer onkoste werklik aangegaan is nie. Daar moet ' $n$ onvoorwaardelike verpligting (Edgars Stores-saak), oftewel ' $n$ 'volstrekte en onvoorwaardelike aanspreeklikheid' (Nasionale Pers Bpk v KBl, 1986 (3) SA 549 (A), 48 SATC 55: 69) bestaan om onkoste as 'werklik aangegaan' te ag.

In die Ackermans-saak het die belastingpligtige geargumenteer dat hy in effek die koper betaal het (deur verrekening) om die voorwaardelike aanspreeklikhede oor te neem, en dat ' $n$ uitgawe dus aangegaan is. Die hof het egter bepaal dat geen uitgawe aangegaan is nie, omrede geen aanspreeklikheid om te betaal deur die verkoper opgeloop is nie. Ingevolge die kontrak was die verkoper nie verplig om iets aan die koper te betaal nie, en die regter het die toepassing van verrekening (set-off) verwerp, aangesien verrekening slegs toepassing vind waar twee partye wedersyds verskuldig is aan mekaar en beide skulde tegelyk ten volle betaalbaar is. Ger en Choong (2011:50) kritiseer egter die hofuitspraak omrede geen oorweging geskenk is aan die belastingpligtige se tweede argument, naamlik dat onkoste aangegaan ter bevryding van voorwaardelike uitgawes, van inkomste aard is nie. Die voorgestelde Konsepwetgewing spreek hierdie vraagstuk aan.

\subsubsection{Voortbrenging van inkomste}

Tweedens moet sogenaamde 'onkostes en verliese werklik aangegaan' ter voortbrenging van inkomste wees. Die 'inkomste' waarna verwys word, word in artikel 1 omskryf, naamlik bruto inkomste minus vrygestelde inkomste.

Waar ' $n$ besigheid as lopende saak verkoop word, ontstaan die probleem dat bedrae betaal aan werknemers by diensbeëindiging, nie by die voortbrenging van inkomste geskied nie. In die saak Port Elizabeth Electric Tramway Co Ltd v CIR, 1936 CPD, is die betekenis van 'by die voortbrenging van inkomste' oorweeg, en is bevind dat onkoste so nou verwant aan sodanige onderneming 
moet wees, dat dit beskou kan word as deel van die koste om dit te bedryf (Stiglingh, Koekemoer, van Schalkwyk, Wilcocks, de Swardt \& Jordaan, 2010:120).

In die geval waar 'n besigheid verkoop word, staak die belastingpligtige sy bedrywighede, en is dit onwaarskynlik dat die werknemers enige verdere inkomste sal voortbring. Huidiglik is dit onwaarskynlik dat die voormalige werkgewer ' $n$ belasting-aftrekking sal kan geniet, aangesien ' $n$ betaling ter beëindiging van ' $n$ besigheid, nie aan die vereiste 'vir die voortbrenging van inkomste' voldoen nie. Konsepwetgewing spreek egter hierdie probleem aan.

\subsubsection{Vir bedryfsdoeleindes}

Derdens laat die inleiding tot artikel 11 slegs aftrekkings toe wat by die beoefening van ' $n$ bedryf aangegaan word. In die saak CIR v Nemojim (Pty) Ltd 1983 (4) SA 935 (A), 45 SATC 241 is bepaal dat die bepalings van artikel 11 (a) ondergeskik is aan die bepalings van artikel $23.0 \mathrm{~m}$ te bepaal of ' $n$ onkoste of verlies aftrekbaar is vir belastingdoeleindes, moet die bedrag ingevolge artikel 23 (g) van die Inkomstebelastingwet vir bedryfsdoeleindes bestee of uitgegee wees.

Weens die Inkomstebelastingwet-vereiste dat geld vir bedryfsdoeleindes bestee of uitgegee is, verander die aftrekbaarheid van verlofbetalings en bonusgelde in die geval waar ' $n$ besigheid beëindig word of selfs verkoop word. Uitgawes aangegaan by die beeïndiging van ' $n$ bedryf is nie 'vir bedryfsdoeleindes' nie, en sal ingevolge huidige wetgewing, waarskynlik nie as ' $n$ aftrekking toegelaat word nie. Konsepwetgewing spreek egter hierdie probleem aan.

\subsubsection{Nie van 'n kapitale aard}

Vervolgens mag onkoste aangegaan by die voortbrenging van inkomste nie van kapitale aard wees nie, maar wel van inkomste-aard synde as ' $\mathrm{n}$ aftrekking te kwalifiseer. 'Inkomste' word deur 'kapitaal' gelewer, soortgelyk aan rente (of vrugte) wat deur die kapitale bedrag (of boom) gelewer word (Stiglingh et al., 2010:28).

In die saak CIR v Visser 8 SATC 271 (bladsy 277), het die belastingpligtige suksesvol onderhandel en die hof het bepaal dat die wins wat hy gemaak het, nie weens die verkoop van ' $n$ kapitale reg was nie, maar deur die gebruik van sy vernuf en energie. 'Inkomste' kan dus beskryf word as 'die produk van ' $n$ man se vernuf en energie', en is belasbaar in die hande van die belastingpligtige.

In die saak New State Areas Ltd v CIR 14 SATC 155 (New State Areas-saak) is die verskil tussen inkomste en kapitaal soos volg verduidelik: uitgawes aangegaan in verband met die inkomsteverdienende bedrywighede van die belastingpligtige, word beskou as inkomste van aard, terwyl uitgawes aangegaan in verband met die inkomsteverdienende struktuur, kapitaal van aard is (Kruger, 2010:22). Konsepwetgewing spreek hierdie probleem aan.

De Bruin (2000) doen aan die hand dat dit onseker is of die voormalige werkgewer ingevolge artikel 11 (a) van die Inkomstebelastingwet, die betaling van ' $n$ spesifieke bedrag aan die voornemende werkgewer om die verpligtinge ten opsigte van uitstaande bonus- en verlofbetalings oor te neem, as ' $n$ belastingaftrekking sal kry. Argumente wat teen die aftrekbaarheid daarvan aangevoer kan word, is die volgende:

- Die betaling wat die voormalige werkgewer maak aan die voornemende werkgewer, is nie ' $n$ uitgawe aangegaan ter voortbrenging van sy inkomste nie, maar eerder ter ontheffing van die voormalige werkgewer se toekomstige onsekere verpligtinge; of 
- Die uitgawe is nie aangegaan by die beoefening van ' $n$ bedryf deur die voormalige werkgewer nie, maar eerder in die loop van die beëindiging van die voormalige werkgewer se bedryf; of

- Die uitgawe is van ' $n$ kapitale aard, omrede dit na die staking van die bedryf van die voormalige werkgewer aangegaan is.

Argumente ten gunste van ' $n$ aftrekking is dat:

- Uitgawes aangegaan om die belastingpligtige te bevry van ' $n$ verpligting (wat indien vervul, ' $n$ aftrekbare uitgawe sou wees), kwalifiseer self as aftrekking, soos gemeld in die sake SIR v John Cullum Construction Co (Pty) Ltd 27 SATC 155 en CIR v VRD Investments (Pty) Ltd 55 SATC 368 (Kruger, 2010:22).

- Dit beskou kan word as ' $n$ uitgawe aangegaan ten opsigte van inkomste wat reeds in die verlede verdien is, (Sub-Nigel Ltd v CIR 1948 (4) SA 580 (A), 15 SATC 381) ('SubNigel-saak'); of

- Dit gedeeltelik aftrekbaar behoort te wees aangesien dit ' $n$ uitgawe is wat ten opsigte van die verdiening van die koopprys, welke gedeeltelik belasbaar kan wees, aangegaan is (De Bruin, 2000). In die New State Areas-saak is die beginsel gevestig dat uitgawes aangegaan in verband met die inkomsteverdienende bedrywighede van die belastingpligtige, inkomste van aard is, terwyl uitgawes aangegaan in verband met die inkomsteverdienende struktuur, kapitaal van aard is (Kruger, 2010:22).

Olivier (2007) meld dat artikel 23B(3) 'n aftrekking ingevolge artikel 11 (a) verbied, indien daar ' $n$ ander artikel in die Inkomstebelastingwet bestaan wat die aftrekbaarheid van die spesifieke uitgawe aanspreek. Artikel $23 \varepsilon$ spreek die bepalings met betrekking tot verlofbetalings aan.

Artikel $23 \varepsilon(2)$ van die Inkomstebelastingwet bepaal spesifiek dat die belastingpligtige geag nie onkoste aan te gegaan het nie ten opsigte van bedoelde verlofgeld totdat dit

- werklik deur hom betaal word of

- deur hom verskuldig en betaalbaar geword het.

De Bruin (2000) is van mening dat die bepalings van artikel 23B(3), saamgelees met artikel $23 \varepsilon(2)$, dus tot gevolg sal hê dat ' $n$ aanspreeklikheid ten opsigte van verlofgeld nie belastingaftrekbaar sal wees voordat dit werklik betaal is, of minstens verskuldig en betaalbaar is nie, ongeag of die aanspreeklikheid om dit te betaal reeds onvoorwaardelik is, of nie.

Uit bogenoemde argumente en hofsake is dit duidelik dat die belastingaftrekbaarheid vir die voormalige werkgewer (verkoper) aanvegbaar is. Kotze (2011) bied hierdie juiste warboel aan as rede vir die Konsepwetgewing wat (na afloop van die Ackermans-saak) ter tafel gelê is. Die voorgestelde Konsepwetgewing bied (uiteindelik) duidelike belastinghantering rakende die verkoper se posisie.

Indien die voormalige werkgewer besluit om nie 'n bedrag te betaal aan die koper vir die oorname van die voorwaardelike aanspreeklikhede nie, kan die koopsom verminder word ter vergoeding vir die oorname.

\subsubsection{Verminder die koopsom deur verrekening}

In die Ackermans-saak is ' $n$ besigheid as lopende saak verkoop en die koopsom ooreenkomstig verminder met die waarde van sommige voorwaardelike aanspreeklikhede wat die koper 
oorgeneem het. Die verkoper was van mening dat die vermindering in koopsom ' $n$ verlies van vermoënskade was, met ander woorde ' $n$ 'uitgawe werklik aangegaan'. Cloete JA het egter bevind dat geen verpligting deur die verkoper opgeloop is (om te betaal) nie, en dat die besigheid bloot verkoop is teen die netto bate waarde, wat nie ' $n$ 'uitgawe werklik aangegaan' is nie.

Emslie (2010:202) is van mening dat indien die besigheid teen ' $n$ hoër prys verkoop is, en die verkoper terselfdertyd ' $n$ 'onvoorwaardelike verpligting om te betaal' onderneem het (sodat die koper die voorwaardelike aanspreeklikhede sal oorneem), die betaling bes moontlik aftrekbaar sou wees. Dieselfde kommersiële resultaat kan dus op verskillende maniere bereik word, met verskillende belastinggevolge.

Ger en Choong (2011:51) is van mening dat die verkoopskontrak so gestruktureer moet wees, dat die verkoper ' $n$ regsverpligting oploop met die oordrag van die voorwaardelike aanspreeklikhede. Die kontrak kan byvoorbeeld bepaal dat die verkoper die koper moet betaal om die voorwaardelike aanspreeklikhede oor te neem, welke betaling/verpligting betaalbaar is op die effektiewe datum van die kontrak. Hierdie betaling/verpligting kan dan deur verrekening van die koopsom plaasvind. Die gevaar verbonde aan hierdie benadering is egter dat die bedoeling van die transaksie gesien kan word om slegs die netto bate waarde van die besigheid te verkoop, en dus geen 'uitgawe' vir belastingdoeleindes erken nie.

Die moontlikheid bestaan dat die voormalige werkgewer ingevolge ' $n$ verhaling belas kan word, in gevalle waar die voormalige werkgewer reeds ' $n$ aftrekking geëis het ingevolge artikel $11(a)$ en wat nie deur artikel $23 \varepsilon$ verbied is nie, en die voornemende werkgewer in werklikheid die krediteure betaal. Die voormalige werkgewer sal belas word ingevolge artikel 8(4)(m). Die bedrag sal gelykstaande wees aan die bedrag van die verpligting waarmee die voormalige werkgewer onthef is. Dit sal egter slegs die geval wees waar dit aangevoer kan word dat die betaling deur die voornemende werkgewer, die voormalige werkgewer onthef het van die verpligting om te betaal, teen geen koste ('for no consideration'). Voorts kan die voormalige werkgewer ' $n$ moontlike verhaling vermy deur aan die voornemende werkgewer ' $n$ spesifieke bedrag te betaal ter oorname van die voorwaardelike aanspreeklikhede, soos reeds voorheen deur die voormalige werkgewer as ' $n$ aftrekking geëis (Olivier, 2007).

Die skrywer is van mening dat indien die voormalige werkgewer die bedrag werklik betaal het aan die voornemende werkgewer, of andersins die koopprys met die ooreenstemmende bedrag verminder het, sodanige bedrag belastingaftrekbaar behoort te wees, omdat die bedrag volgens kontrak verskuldig en betaalbaar geword het.

Die skrywer is voorts van mening dat die voormalige werkgewer slegs ' $n$ moontlike verhaling ingevolge artikel $8(4)(\mathrm{m})$ in die gesig sal staar in gevalle waar die werklike verpligting die bedrag te bowe gaan wat die voormalige werkgewer aan die voornemende werkgewer betaal het, of alternatiewelik indien die koopprys daarmee verminder is.

\subsection{Betaal bedrag op datum betaalbaar aan voormalige werknemer}

Die voormalige werkgewer word ingevolge artikel 197 van die Arbeidsverhoudingewet verbind tot enige bedrae betaalbaar soos vermeld in die kontrak op datum van oordrag, of vir enige bedrae betaalbaar weens die ontslag van werknemers of weens die voornemende werkgewer se likwidasie of sekwestrasie.

Olivier (2007) beveel aan dat die voormalige werkgewer nie enige verpligtinge om verlof- of bonusbetalings te maak na datum van oordrag, moet behou nie. Ingevolge artikel 11 (a) van die 
Inkomstebelastingwet, mag sulke betalings deur voormalige werkgewers moontlik nie as 'aangegaan ter voortbrenging van inkomste' of 'vir bedryfsdoeleindes' beskou word nie.

Weens die gesamentlike en afsonderlike verpligting wat die voormalige werkgewer ingevolge die Arbeidsverhoudingewet opgelê word, is die skrywer van mening dat ' $n$ belastingaftrekking egter aan die voormalige werkgewer toegestaan moet word in gevalle waar die voormalige werkgewer die bedrag betaal aan die werknemers, soos en wanneer dit onvoorwaardelik word. Hierdie belastingaftrekking moet toegestaan word selfs al vind die betaling plaas op ' $n$ datum na oordrag wanneer die voormalige werkgewer al in wese 'bedrywighede gestaak het'. Die rede vir hierdie sienswyse is die riglyn, soos neergelê in die Sub-Nigel-saak, waar bevind is dat uitgawes aangegaan ten opsigte van inkomste wat reeds in die verlede verdien is, belastingaftrekbaar behoort te wees. Die werknemers sal belas word op hierdie ontvangste, en geen verdere regte behou rakende die betaalde bonusse of verlofgelde nie.

Artikel $23 \varepsilon(2)$ (a) van die Inkomstebelastingwet, bepaal dat die belastingpligtige geag word nie onkoste aan te gegaan het nie ten opsigte van bedoelde verlofgeld, totdat dit werklik deur hom betaal word of deur hom verskuldig en betaalbaar geword het. Die werknemers word voorts op die bedrag belas wat die belastingpligtige as aftrekking eis.

Voorts is die skrywer van mening dat die voormalige werkgewer aan wetgewing moet voldoen en alle stawende dokumentasie, (soos vereis deur artikel 197 van die Arbeidsverhoudingewet), by te hou. Sodoende sal voldoende bewys bestaan dat die betaling plaasgevind het ingevolge ' $n$ regsverpligting, soos opgelê deur die Arbeidsverhoudingewet.

Nadat die vereistes van artikel 11 (a) ondersoek is, moet die bepalings van artikels 23 en $23 \varepsilon$ van die Inkomstebelastingwet ondersoek word. Laasgenoemde artikels verbied sekere aftrekkings wat wel aan die vereistes van artikel 11 (a) voldoen.

\subsection{Gelde oorgedra na 'n fonds}

Artikel 23(e) van die Inkomstebelastingwet bepaal dat die oordrag van fondse na ' $\mathrm{n}$ reserwefonds nie aftrekbaar is vir belastingdoeleindes nie. Hierdie situasie word gevolglik nie verder bespreek nie.

Die belastingaftrekbaarheid wat die voornemende werkgewer kan geniet / al dan nie, word vervolgens bespreek.

\section{BELASTINGAFTREKBAARHEID VIR DIE VOORNEMENDE WERKGEWER (KOPER)}

Die voornemende werkgewer wat ingestem het om die voorwaardelike verpligtinge oor te neem, sou ' $n$ bedrag, hetsy in kontant, of deur verrekening van die koopsom, as vergoeding ontvang het. Vervolgens sal die voornemende werkgewer dan ook ' $n$ betaling aan die werknemers moet maak, soos en wanneer die voorwaardelike aanspreeklikhede realiseer.

\subsection{Ontvang bedrag vanaf voormalige werkgewer (verkoper)}

Die voornemende werkgewer kan onderhandel om die bedrag in kontant te ontvang, of andersins ' $n$ vermindering (deur verrekening) van die koopsom aanvaar. 


\subsubsection{Ontvang bedrag vanaf verkoper op datum van oordrag}

Artikel $l$ van die Inkomstebelastingwet bepaal dat ' $n$ bedrag ontvang, vanuit ' $n$ Suid-Afrikaanse bron, en wat nie van ' $n$ kapitale aard is nie, bruto inkomste en dus belasbaar sal wees in die hande van die ontvangende party.

In die geval waar die voornemende werkgewer dus ' $n$ bedrag ontvang vanaf die voormalige werkgewer as 'vergoeding' vir die oorname van die toekomstige onsekere verpligtinge, sal die voornemende werkgewer waarskynlik op die ontvangste belas word. Die voornemende werkgewer kan egter verligting verkry deurdat artikel $24 \mathrm{C}$ (2) van die Inkomstebelastingwet voorsiening maak vir die aftrekking van bedrae wat ' $n$ belastingpligtige ontvang het ingevolge ' $n$ kontrak en wat aangewend moet word om toekomstige onkoste te finansier wat voortspruit uit die nakoming van verpligtinge ingevolge die kontrak. Die bedrag wat ingevolge artikel $24 C(2)$ as ' $n$ aftrekking in ' $n$ vorige jaar toegelaat is, moet jaarliks ingevolge artikel $24 C(3)$ by die voornemende werkgewer se belasbare inkomste ingesluit word, met die toepaslike artikel $24 C(2)$-aftrekking, of uiteindelik, ' $n$ artikel $11(a)$ aftrekking daarteen (De Bruin,2000). Konsepwetgewing spreek hierdie situasie aan.

\subsubsection{Aanvaar vermindering van koopsom deur verrekening}

Die belastingimplikasies op die voornemende koper in geval waar ' $n$ vermindering van koopprys deur verrekening aanvaar word, sal in ' $n$ volgende artikel bespreek word.

\subsection{Betaal bedrag op datum betaalbaar aan werknemer}

Olivier (2007) is van mening dat indien die voornemende werkgewer die werknemerskontrakte oorneem (ingevolge die verpligtinge soos opgelê deur die Arbeidsverhoudingewet), en uiteindelik die bonusse of verlofverpligtinge ingevolge die kontrakte betaal, sal die voornemende werkgewer ' $n$ uitgawe aangaan ter voortbrenging van inkomste.

Bogenoemde siening is bevestig in die obiter dictum, soos uitgespreek in die Ackermans-saak, maar Ger en Choong (2011) bevraagteken egter hierdie obiter dictum. Hulle is van mening dat die koper nie geregtig is op ' $n$ aftrekking nie, synde die verpligting in so ' $n$ geval aangegaan, ter verkryging van die besigheid was (dus kapitaal van aard). Kruger (2010:23) beaam hierdie siening synde dat dit verband hou met die koste ter verkryging van ' $n$ inkomste verdienende struktuur. Hierdie sienswyse word ook ondersteun deur die New Zealand-saak Commissioner of Inland Revenue $v$ New Zealand Forest Research Institute Ltd (2000) STC 522 (PC) waar bepaal is dat uitgawes aangegaan ter vervulling van voorwaardelike aanspreeklikhede oorgeneem, deel is van die koopsom wat kapitaal van aard is, en daarom nie aftrekbaar nie (Gad, 2011).

Uit bostaande blyk dit dat daar tans uiteenlopende opinies bestaan rakende die aftrekbaarheid van voorwaardelike aanspreeklikhede vir die voornemende koper. Die voorgestelde Konsepwetgewing spreek hierdie probleem gedeeltelik aan.

\section{BEPALINGS INGEVOLGE DIE WET OP ARBEIDSVERHOUDINGE (ARBEIDSVERHOUDINGEWET)}

Volgens die gemenereg vorm die dienskontrak die basis van die verhouding tussen die werknemer en werkgewer (Grogan, 2009). Voorts bepaal dit dat, wanneer ' $n$ besigheid verkoop word, geen werknemer verplig mag word om sy dienskontrak met die voornemende werkgewer voort te sit 
nie. Andersyds bepaal dit dat die voornemende werkgewer nie verplig is om die dienskontrakte oor te neem nie. Die gemenereg bied dus geen beskerming aan werknemers se werksekuriteit in die geval van ' $n$ oordrag van ' $n$ besigheid as lopende saak nie (Abader, 2003).

Artikel 197(2) van die Arbeidsverhoudingewet reguleer die oordrag van ' $n$ besigheid as lopende saak. Artikel 197(1), bygestaan deur artikel 197(2) beskerm die werksekuriteit van werknemers, aangesien artikel 197(2) 'n aantal vereistes daarstel.

Voordat artikel 197 egter ondersoek word, word die omskrywings van 'werknemer' en 'besigheid' bespreek.

\subsection{Werknemer}

Ingevolge artikel 213 van die Arbeidsverhoudingewet is ' $n$ werknemer ' $n$ persoon wat sy arbeidspotensiaal tot die beskikking van 'n ander persoon, onder daardie persoon se beheer en gesag, stel en wat geregtig is om vergoeding daarvoor te ontvang. Voorts sluit dit ook in enigiemand wat op enige wyse hoegenaamd ' $n$ ander help om sy besigheid voort te sit of te bedryf en wat geregtig is om vergoeding te ontvang. Artikel 2 van die Arbeidsverhoudingewet sluit egter uitdruklik drie kategorieë van werknemers uit, naamlik: die Nasionale Weermag, die Suid-Afrikaanse Geheimediens en die Nasionale Intelligensie Agentskap. Behalwe vir die vermelde drie groepe word alle ander werknemers ingesluit, dus ook amptenare van die openbare sektor, plaaswerkers, huiswerkers, ensovoorts.

\subsection{Besigheid}

Barker en Holtzhausen (soos aangehaal deur Smit, 1997) omskryf ' $n$ 'onderneming' soos volg:

"An independent economic organization with the object of making capital invested therein profitable by supplying goods or services on a continuous basis to the market in anticipation of a demand for such goods or services"

\subsection{Artikel 197 van die Arbeidsverhoudingewet}

Volgens artikel 197(2)(a) word die voornemende werkgewer onmiddellik in die plek van die voormalige werkgewer gestel. Alle dienskontrakte word dus deur die voornemende werkgewer oorgeneem. Artikel 197(2)(b) bevestig dat alle regte en verpligtinge wat voor die oordrag bestaan het tussen die werkgewer en elke werknemer, geag word voort te bestaan tussen die voornemende werkgewer en elke werknemer. Artikel 197(2)(c) bepaal dat enigiets gedoen voor die oordrag deur of in verband met die voormalige werkgewer, ook geag word gedoen te wees deur of in verband met die voornemende werkgewer. Artikel 197(2)(d) stel dit duidelik dat die oordrag geensins die werknemer se indiensneming onderbreek nie, en die dienskontrak gaan voort met die voornemende werkgewer, asof hy die voormalige werkgewer is.

Artikel 197(2) waarborg werksekuriteit op dieselfde terme en voorwaardes na die oordrag, met geen onderbreking van die dienskontrak nie (Smit, 2005).

Smit (2003) bevestig die interpretasie van artikel 197(2), wat bepaal dat die voornemende werkgewer outomaties in die plek van die voormalige werkgewer gestel word ten opsigte van alle dienskontrakte wat bestaan het onmiddellik voor die datum van oordrag. 
Die woorde 'onmiddellik voor die oordrag', moet volgens Bosch (2004:935) ook gelees word as 'tydens' (die oordrag). Indien dit nie so gelees word nie, sal artikel 197 kontrakte wat reeds bestaan het voor, maar nie tydens die oordrag, weer laat herleef.

Werknemervoordele word verder beveilig deur die bepalings van artikel 197(2)(b) - (d). Alle regte en verpligtinge tussen die voormalige werkgewer en elke werknemer bly van krag, die voornemende werkgewer is aanspreeklik vir die optredes van die voormalige werkgewer (veral afdankings, diskriminasie en onbillike arbeidspraktyke) en die werknemer se jare van diens word na die voornemende werkgewer oorgedra. Artikel 197 fasiliteer dus die oordrag van ' $n$ indiensnemingverhouding en nie slegs die oordrag van indiensnemingkontrakte nie. Verhoudings met werknemerverteenwoordigers word oorgedra in die mate dat, in terme van artikel 197(5), kollektiewe ooreenkomste en arbitrasie uitsprake, wat die voormalige werkgewer gebind het ten opsigte van die oordrag van werknemers, ook die nuwe werknemer sal bind na oordrag. Sekere kollektiewe ooreenkomste wat bestaan het tussen die voormalige werkgewer en geregistreerde vakbond sal na die voornemende werkgewer oorgedra word. Die voornemende werkgewer sal egter nie gebonde wees aan ooreenkomste wat regte aan vakbonde eerder as werknemers toeken nie (Bosch, 2004).

Volgens Bosch (2004) plaas sub-artikel 197(7) 'n verpligting op die voormalige werkgewer om met die voornemende werkgewer ooreen te kom, rakende die waarde van sekere betalings wat ten gunste van elke werknemer opgeloop het op datum van oordrag. Voorts moet hulle ooreenkom wie vir die betalings, asook watter gedeeltes, aanspreeklik sal wees. Ingevolge artikel $197(7)$ is die werkgewers gesamentlik en afsonderlik aanspreeklik vir 'n periode van 12 maande na die oordrag, indien die bedrae betaalbaar word weens afdanking of die likwidasie of sekwestrasie van die voornemende werkgewer.

Smit (2003) is van mening dat die periode van 12 maande, waartydens die voormalige werkgewer en voornemende werkgewer gesamentlik en afsonderlik aanspreeklik gehou kan word, ten doel het om bedrieglike oordragte te bekamp.

Die voormalige en voornemende werkgewer is voorts gesamentlik en afsonderlik aanspreeklik vir enige eis met betrekking tot enige bepaling of diensvoorwaarde wat die oordrag voorafgegaan het. Die werknemer, aan die ander kant, behou geen vatbaarheid vir vervolging, veroordeling van, of vonnis vir enige misdryf begaan voor oordrag nie (Smit, 2003).

Bosch (2004) is van mening dat artikel 197 sodanig geïnterpreteer moet word om effek te gee aan die doelwitte en oogmerke van die Arbeidsverhoudingewet. Artikel 197 moet daarom toegepas word in ooreenstemming met die regte, soos vervat in artikel 23 van die Grondwet, ter bevordering van ekonomiese ontwikkeling, sosiale geregtigheid en arbeidsvrede.

Die Arbeidsverhoudingewet plaas ' $n$ aantal verpligtinge op beide die voormalige en voornemende werkgewer, ten einde werknemers se werksekuriteit te beskerm.

Indien wetgewing die oorname van onsuksesvolle besighede onaantreklik laat lyk, kan dit tot die likwidasie van besighede lei, eerder as die verkoop daarvan. Werknemers se werksekuriteit sal dan in gedrang wees, en hierdie gevolg het juis die teenoorgestelde uitwerking as die aanvanklike oogmerke van artikel 197 van die Arbeidsverhoudingewet (Abader, 2003). 


\section{KONSEPWETGEWING}

Op 2 Junie 2011 het Nasionale Tesourie konsep 'Taxation Laws Amendment Bill, 2011' ter tafel gelê. Alhoewel die Konsepwetgewing kan verander, gee dit ' $n$ goeie aanduiding van hoe die finale wetsontwerp daar sal uitsien (Wild, 2011). Die voorgestelde wetswysiging raak van krag in 2012 (Williams, 2011).

Die voorgestelde nuwe bepalings ingevolge artikel $11 \mathrm{~F}$ van die 'Draft Taxation Laws Amendment Bill 2011' stel die volgende voor:

- Die wetswysiging maak dit duidelik dat die verkoper geregtig is op ' $n$ aftrekking.

- 'n Spesiale statutêre regime sal in werking gestel word om te verhoed dat beide die verkoper en koper dieselfde aftrekking geniet.

- Die verkoper word verplig om die waarde van die voorwaardelike aanspreeklikhede (wat oorgedra word aan die koper) by sy bruto inkomste of kapitaalwins te voeg (na gelang dit rakende handelsvoorraad of kapitale bates is). Hierdie waarde moet gebaseer word op die billike markwaarde, en nie die sigwaarde nie.

- Die waarde van die voorwaardelike aanspreeklikhede deur die koper oorgeneem, sal bygevoeg word by die kosprys of basiskoste (afhangend of dit handelsvoorraad of ' $n$ kapitale bate is). Terselfdertyd sal die koper ' $n$ gelykstaande bedrag as toelaag geniet. Hierdie toelaag sal jaarliks teruggetel word en vorentoe rol in die daaropvolgende jare, en verminder soos betalings ten opsigte van die voorwaardelike aanspreeklikhede realiseer of verwyderd raak (Williams, 2011).

Dit voorgestelde Konsepwetgewing bied (uiteindelik) duidelike belastingverligting by die verkoop van 'n besigheid as lopende saak, en hierdie Konsepwetgewing behoort verwelkom te wees. Kleynhans (2011) is egter van mening dat sekere omskrywings, soos 'kapitaal' en 'inkomste' nie duidelik in die voorstel uiteengesit word nie. Voorts word die konsep 'voorwaardelike aanspreeklikhede' ook nie omskryf nie.

Konsepwetgewing spreek tans nie die probleme wat die koper ervaar aan nie. Ook ontbreek die behoefte om die bepalings van die Arbeidsverhoudingewet te belyn met die bepalings van die Inkomstebelastingwet. Hierdie probleme sal in ' $n$ volgende artikel bespreek word.

\section{GEVOLGTREKKING}

In hierdie artikel is daar ondersoek ingestel na die Arbeidsverhoudingewet om te bepaal in watter omstandighede die voormalige of voornemende werkgewer verplig word om werknemerverwante betalings te maak nadat ' $n$ besigheid as lopende saak verkoop is. Dit is voorafgegaan deur ' $n$ ondersoek van die Inkomstebelastingwet en die vereistes waaraan werknemerverwante betalings moet voldoen om as aftrekkings toegestaan te word.

In die geval van die verkoop van 'n besigheid as lopende saak, word die voornemende werkgewer ingevolge artikel 197 van die Arbeidsverhoudingewet verplig om alle dienskontrakte, tesame met alle regte en verpligtinge wat bestaan tydens die oordrag, oor te neem asof hy in wese in die skoene tree van die voormalige werkgewer. Voorts word die voormalige werkgewer ook gebind aan die betaling van bedrae, soos en wanneer dit betaalbaar word, in gevalle waar die verkoopskontrak bepaal, of andersins in gevalle waar die voornemende werkgewer nie die 
verpligting om te betaal, kan nakom nie. Daar rus dus 'n wetlike verpligting (soos neergelê deur die Arbeidsverhoudingewet) op beide die voormalige sowel as voornemende werkgewer in die geval waar ' $n$ besigheid as lopende saak verkoop word.

In teenstelling hiermee, wil dit voorkom asof die huidige Inkomstebelastingwet geen duidelike belastingaftrekking sal toestaan aan die voormalige werkgewer wat ' $n$ betaling maak uit hoofde van die werkskontrak nie. Die voornemende werkgewer is voorts ook nie in ' $n$ beter posisie nie. Alhoewel die voornemende werkgewer sal kan bewys dat voldoen word aan alle voorwaardes ten einde ' $n$ aftrekking te geniet (wanneer die betaling gemaak word), indien die kontrak daarvoor voorsiening maak, word die aftrekking voorafgegaan deur die insluiting van die bedrag ontvang vanaf die voormalige werkgewer (die verkoper) by die voornemende werkgewer (die koper) se bruto inkomste, indien so 'n betaling wel gemaak word.

Indien die Inkomstebelastingwet nie die oogmerke van die Arbeidsverhoudingewet ondersteun nie, mag dit nadelig wees aangesien die belastingpligtige sy besluite baseer op die beste ekonomiese gevolg vir hom as ondernemer. Die belastingpligtige sal dus in gevalle waar die Arbeidsverhoudingewet ' $n$ verpligting daarstel, en die Inkomstebelastingwet geen aftrekking bied nie, bes moontlik kies om nie die verpligting op te neem nie. So 'n besluit mag moontlik tot gevolg hê dat alle werknemers afgedank word alvorens ' $n$ besigheid van die hand gesit word. ' $n$ Positiewe omgewing daarenteen, waar die Inkomstebelastingwet die oogmerke van die Arbeidsverhoudingewet ondersteun, sal egter die oordrag van besighede fasiliteer en werknemers beskerm.

Tans bestaan daar ' $n$ posisie waar die Arbeidsverhoudingewet ' $n$ verpligting op beide die voormalige sowel as voornemende werkgewer plaas, met geen gepaardgaande/ ondersteunende Inkomstebelastingwetgewing nie. Aangesien die belastingpligtige sy ekonomiese besluite baseer op afdwingbare wetgewing (bv die bepalings ingevolge die Arbeidsverhoudingewet) asook goeie besigheidsvernuf, is hierdie situasie onregverdig. Die Inkomstebelastingwetgewing behoort eerder ekonomiese rasionaliteit en goeie besigheidsvernuf te ondersteun, om sodoende ' $n$ positiewe omgewing te skep waarbinne die belastingpligtige sy sake kan verrig.

Hofsake is bespreek in hierdie artikel wat telkens uitgewys het dat die aftrekbaarheid van werknemerverwante voorwaardelike aanspreeklikhede, ingevolge huidige Inkomstebelastingwetgewing, onduidelik is. Dit blyk egter dat die voorgestelde Inkomstebelastingwetswysigings hierdie vraagstuk oplos. Hierdie wetswysigings moet egter ook die oogmerke van die Arbeidsverhoudingewet ondersteun.

Dit word aanbeveel dat indien ' $n$ voormalige of voornemende werkgewer dus ' $n$ werknemerverwantebetaling maak uit hoofde van die wet soos neergelê deur die Arbeidsverhoudingewet, die Inkomstebelastingwet aan die werkgewer wat die betaling maak, die betrokke belastingaftrekking behoort toe te staan. Sodoende sal die Inkomstebelastingwet die oogmerke van die Arbeidsverhoudingewet onderskraag.

\section{BRONNELYS}

Abader, M.S. (2003). The labour law consequences of a transfer of a business. Ongepubliseerde Magister Legum-tesis. Port Elizabeth: Universiteit van Port Elizabeth.

Ackermans Ltd v CSARS, PEP Store (SA) Ltd v CSARS 2011 (1) SA 1 (SCA) 
Bosch, C. (2004). Balancing the act: fairness and transfers of businesses. Industrial Law Journal 25 IL): 923-943.

CIR v Nemojim (Pty) Ltd 1983 (4) SA 935 (A), 45 SATC 241

CIR v Visser 8 SATC 271

CIR v VRD Investments (Pty) Ltd 55 SATC 368

Commissioner of Inland Revenue v New Zealand Forest Research Institute Ltd (2000) STC 522 (PC)

De Bruin, MM. (2000). Belastingoorwegings om in gedagte te hou by samesmeltings en oornames van Suid-Afrikaanse maatskappye. Ongepubliseerde MComm(Belasting)-tesis. Stellenbosch: Universiteit van Stellenbosch.

Edgars Stores Ltd v CIR, 1988 (3) SA 764 (A), 50 SATC 81

Emslie, T. (2010). A quartet from the SCA. The Taxpayer, 59(11\& 12), p. 202

Gad, R. (2011). Transfer of contingent liabilities - legis/ation on the horizon? [Intyds]. Beskikbaar: http://www.ens.co.za. (Toegang 31 Maart 2011)

Ger, B. (2009). The problem with 'provisions' when purchasing a business. The South African Institute of Tax Practitioners. [Intyds]. Beskikbaar: http://www.thesait.org.za/news det.asp?ID=205.

(Toegang 16 Oktober 2009)

Ger, B. (2011). Is the problem with 'provisions' upon purchase of a business, resolved? [Intyds].

Beskikbaar: http://www.kpmg.com/za/en/issuesandinsights/articlespublications/tax-and-legalpublications. (Toegang 17 Augustus 2011)

Ger, B. \& Choong, J. (2011). Sale of a busines having contingent liabilities: Revisited. De Rebus -SA Attorney's Journal. [Intyds]. Beskikbaar: http://www.myvirtualpaper.com/doc/derebus/de_rebus_january_2011. (Toegang 17 Augustus 2011)

Grogan, J. (2009). Workplace Law. (ed. 10). Lansdowne: Juta Law.

Joffe \& Co (Pty) Ltd v CIR, 13 SATC 354

Kleynhans, S. (2011). Contingent liabilities on sale of a business. [Intyds]. Beskikbaar: http://www.ey.com. (Toegang 28 Junie 2011)

Kotze, J. (2011). Draft taxation laws amendment bill. [Intyds]. Beskikbaar: http://www.bowman.co.za/LawArticles/Index.asp\#articles. (Toegang 2 Augustus 2011)

Kruger, D. (2010). The Sale of a Business: the assumption of liabilities in part settlement of the purchase price and the VAT implications where the corporate rules apply. Business Tax \& Company Law Quarterly, 1(4):17-26.

Nasionale Pers Bpk v KBI, 1986 (3) SA 549 (A), 48 SATC 55

New State Areas Ltd v CIR 14 SATC 155

Port Elizabeth Electric Tramway Co Ltd v CIR, 1936 CPD

Olivier, Prof L. (2007). Tax implications of the sale of a business. SA Law Journal, 124(3):600-617.

Republiek van Suid-Afrika. (2011). Draft Taxation Laws Amendment Bill. [Intyds]. Beskikbaar: http://www.treasury.gov za. (Toegang 28 Julie 2011).

Republiek van Suid-Afrika. (1962). Inkomstebelastingwet Nr. 58 van 1962. Pretoria: Staatsdrukkery. 
Republiek van Suid-Afrika. (1995). Wet op Arbeidsverhoudinge 66 van 1995. Pretoria: Staatsdrukkery. Schutte \& Others v Powerplus Performance (Pty) and Another 19992 BLLR 169 (LC)

SIR v John Cullum Construction Co (Pty) Ltd 27 SATC 155

Smit, N. (2005). A chronicle of issues raised in the course of dismissals by the transferor and/or transferee in circumstances involving the transfer of an undertaking. Industrial Law Journal 26/L): 1853-1896.

Smit, N. 2003. Automatic transfer of emloyment contracts and the power to object. Tydskrif vir die Suid-Afrikaanse reg, 9 (3): 465-489.

Smit, N. 1997. Word werksekuriteit gewaarborg in die lig van artikel 197 van die wet op arbeidsverhoudinge 66 van 1995. Tydskrif vir die Suid-Afrikaanse reg,(13(3):548-558)

Steenkamp, P.B. (1993). ' $n$ Oorweging van die term 'onkoste werklik aangegaan' in die inkomstebelastingwet, met spesifieke verwysing na voorsiening vir verlofgelde. Ongepubliseerde LL Magistertesis. Kaapstad: Universiteit van Kaapstad.

Stiglingh, M., Koekemoer, A.D., van Schalkwyk, L., Wilcocks, J.S., de Swardt, R.D. \& Jordaan, K. (2010). SILKE : Suid-Afrikaanse Inkomstebelasting 2010. Durban: LexisNexis.

Sub-Nigel Ltd v CIR 1948 (4) SA 580 (A), 15 SATC 381

The 0xford English Dictionary (online edition). (Accessed 30 August 2010)

Vorster,Q., Koornhof,C., Oberholster, J.G.I., Koppeschaar, Z.R., Coetzee, S.A., Janse van Rensburg, C., Binnekade, C.S., Hattingh, M. \& Leith, K. (2009). Beskrywende Rekeningkunde IFRS-Fokus. Durban: LexisNexis.

Wild, M. (2011). Draft taxation laws amendment bill, 2011. [Intyds]. Beskikbaar: http://www.cm.law.za. (Toegang 28 Julie 2011).

Williams, R.C. (2011). The deduction of contingent expenditure in going concern sales as envisaged in the current draft Taxation Laws Amendment Bill. Synopsis Tax today. [Intyds]. Beskikbaar: http://www.pwc.com/za/synopsis. (Toegang 28 Julie 2011) 